\title{
P3-528
}

[WG1] Soil Monitoring for Mankind and Environment Safety

\section{Efficiency of Sulfur Application on Soybean in Two Types of Oxisols in Southern Brazil}

\author{
$\underline{\text { Adonis Moreira }}^{1 *}$, Gedi Sfredo $^{1}$, Larissa Moraes $^{2}$ and Nand Fageria ${ }^{3}$ \\ 1 Soil Science, Embrapa Soybean, Brazil \\ ${ }^{2}$ Department of Plant Sciences, Embrapa Soybean, Brazil \\ ${ }^{3}$ Soil Science, Embrapa Rice and Bean, Brazil \\ adonis.moreira@embrapa.br
}

Modern agricultural techniques have been increasing the yield of soybean (Glycine max L.) while also causing increasing removal of sulfur (S) from the soil. Besides this, the use of concentrated fertilizers with this element and inadequate soil management, with consequent formation of organic matter with low $\mathrm{S}$ concentrations, has been causing frequent symptoms if deficiency in the plats. To assess the effect of S on soybean yield and to establish critical levels of S-SO42- available in the soil, two experiments were conducted over a two-year period in the Parana State, Brazil, in fields containing Typic Haplorthox and Typic Eutrorthox soils, located in the municipalities of Ponta Grossa and Londrina, respectively. The experimental design was randomized blocks with five $\mathrm{S}$ rates $(0,25,50,75$, and $100 \mathrm{~kg}$ ha-1) and four replicates. The source used was elementary $\mathrm{S}$ with $98 \%$ purity. The maximum estimated yields on average for the two years were obtained with application of 49.9 and $63.0 \mathrm{~kg}$ ha-1 in the Typic Haplorthox and Typic Eutrorthox soils, for an overall average of $56.4 \mathrm{~kg}$ ha-1, with S-SO42- concentrations in the 0-20 cm depth of $16.9,19.3$ and $17.1 \mathrm{mg} \mathrm{kg}-1$, respectively, values higher than the $10 \mathrm{mg} \mathrm{kg}-1$ indicated as the adequate concentration for soybean plant. In turn, at the 21-40 cm depth, the $\mathrm{S}$ concentrations were 49.5, 74.2 and $56.4 \mathrm{~kg}$ ha- 1 . The efficiency of the fertilization diminished with increasing $\mathrm{S}$ rates, in both soil types, while the greatest yield efficiency was obtained in the plants grown in the Typic Haplorthox soil. 